Interfaces

\title{
"San Francisco on a thousand plates": New perspectives on photo-historical research around 1900 through the lens of the California Camera Club
}

\section{Carolin Görgen}

\section{(2) OpenEdition}

\section{Journals}

Electronic version

URL: http://journals.openedition.org/interfaces/644

DOI: 10.4000/interfaces.644

ISSN: 2647-6754

\section{Publisher:}

Université de Bourgogne, Université de Paris, College of the Holy Cross

\section{Printed version}

Date of publication: 21 June 2019

Number of pages: 7-24

ISSN: 1164-6225

\section{Electronic reference}

Carolin Görgen, "'San Francisco on a thousand plates": New perspectives on photo-historical research around 1900 through the lens of the California Camera Club", Interfaces [Online], 41 | 2019, Online since 21 June 2019, connection on 07 January 2021. URL: http://journals.openedition.org/interfaces/ 644 ; DOI: https://doi.org/10.4000/interfaces.644

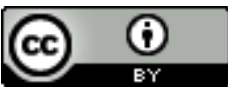

Les contenus de la revue Interfaces sont mis à disposition selon les termes de la Licence Creative Commons Attribution 4.0 International. 


\title{
"SAN FRANCISCO ON A THOUSAND PLATES": NEW PERSPECTIVES ON PHOTO-HISTORICAL RESEARCH AROUND 1900 THROUGH THE LENS OF THE CALIFORNIA CAMERA CLUB
}

\author{
Carolin Görgen \\ Université Paris VII Denis Diderot
}

In the fall of 1901, when the San Francisco-based California Camera Club had just celebrated its tenth anniversary, its president James W. Erwin published an appeal in the West Coast photography journal Camera Craft ${ }^{1}$. Amid heated discussions of Pictorialist salons and an emerging 'Secessionist' strand in New York, Erwin reached out to the broad base of practitioners located at the other end of the continent. His aim was to organize an excursion in which San Francisco was to be systematically photographed. In the shape of "a photographic army to impress [the city] on a thousand plates," members would divide the map into equal slices and cover venues like City Hall, Golden Gate Park, churches, libraries and businesses. "The best things secured" from this outing, that is, some 125 images, were to be preserved as prints in the club rooms in San Francisco and, in addition, circulated in the American Lantern Slide Interchange - an organization which allowed clubs across the country to share sets of views (Erwin, "A Photographic Army" 237-38). While this project to represent urban progress was hardly new-given San Francisco's production of albums illustrating "ideals of community" since the 1850s (Birt 100) - it did constitute a novel approach in requiring the large-scale participation of local photographers. As such, the announcement received attention in the national photographic press, which praised its systematicity and suggested nationwide storage venues ("National"). As opposed to the traditional conception of camera clubs around 1900 as striving for their legitimate place amid the fine arts, Erwin's project voices a considerable concern for historical preservation. It took its inspiration from the British National Photographic Records Association (NPRA), founded in 1897, whose camera club members documented the national territory and contributed to a collection at the British Museum (Edwards 35-36). Erwin's desired archive containing "a thousand plates"-and its first being suggested by a club removed from the nation's cultural centers - points to the widely felt necessity among resident photographers for a coherent visual history of their community (Erwin, "A Photographic Army" 237).

1. This article is dedicated to the memory of my wonderful supervisor François Brunet. His unceasing support and generosity have allowed this research to take shape. 
Yet inasmuch as the city incited its thriving photographer circles to produce a visual archive, it also had a considerable record of earthquakes and fires - the most damaging of which occurred five years after the Club's project, in April 1906. The sixty seconds of tremor and subsequent three days of fire destroyed seventy-five percent of the city, left more than half of the population of 410,000 homeless, and took a death toll of an estimated 3,000 (Fradkin 187-91). In the light of this destruction, the earthquake is thought to have set an end to the Bay Area's photographic scene-and thus, in the long run, to have hampered the articulation of a history of Californian photography in the early twentieth century (Wilson 12-17; Miottel 26-27). While it holds true that the catastrophe has left conspicuous gaps, a closer look at the period after 1906 suggests that the event triggered a massive photographic production that would rapidly refill the archive (Görgen, "Des cendres à la nouvelle métropole" 186-99). By 1910, Club members - as a reassembled "photographic army" - relaunched their urban survey in an attempt to reconstruct the profound changes the city had undergone in a decade. This project is one out of many, documented in Camera Craft, which counter the idea of a photographic void after 1906. If the seeming absence of Californian practitioners in this period has remained a vexing question to scholars and curators, this omission seems mostly due to a persistent concern of American photo-historical scholarship with the narrative of the New York Photo-Secession and its focus on fine-art institutions that were founded long after the earthquake and fire (Naef; Kroiz; McCauley).

Despite the fact that the California Camera Club's remarkable membership of 425 in 1900 did not generate a coherent archive, the local-historical institutions that had been formed in San Francisco from the mid nineteenth century in fact allow researchers to retrieve a substantial body of work. As recent findings by European scholars have demonstrated, the exploration of the social dynamics, local practices, and material culture of camera clubs around 1900 generates new understandings of their output (Edwards; Joschke). The Californian practitioners, when examined through this lens, manifest similar expectations of the medium with regard to local history and community building (Watts; Görgen "Out here"). Key to understanding this awareness is the Club's membership which included wealthy inhabitants of the Bay Area, artists, and professional photographers of the region's foremost business - the Southern Pacific Railroad Company. Through these ties to businesses, politicians, and cultural institutions, the Club's photographic production was put to a variety of uses and became closely interwoven with the development of the community.

It is exactly this awareness of photography's usefulness to the solidification of a Northern Californian culture that will be taken as a point of departure to demonstrate how the archive of a largely forgotten camera club can be reconstructed. Moving from a fine-art-centered narrative of American photography toward a "history of photographic uses" (Solomon-Godeau xxiv), we can unearth a body of highly eclectic works which testify to the usefulness of the photographic medium to the construction 
of a shared local identity. What is at stake here is the re-appreciation of a Californian photographic corpus that has been long overlooked due to the destruction of the earthquake and the absence of a West Coast equivalent to Alfred Stieglitz's Photo-Secession. By mobilizing sources of the Club's most active period around 1900, this article allows for a new set of actors, practices, and modes of dissemination to emerge. By reconstructing parts of the corpus of this more than 400-member-strong organization and by retracing the Club's story of disappearance, we may grasp how photographic materiality, storage locations and institutional appreciation have informed both the history of the medium and its tools of archival inquiry.

\section{Surveying the sources: The identification of a Club corpus}

While research in Europe has shed new light on the role of collective photography in the creation of meaningful local histories in the period of emerging nationhood (Edwards), it appears that similar desires were articulated in the late-nineteenth-century American West. In a region whose landscape evoked, according to historian Martha Sandweiss, unequaled imaginary scenarios to American publics, resident photographers sought to unfold this potential in their work (13). Drawing on California's promise of material riches and lavish landscapes since the Gold Rush of 1848, the Club's early projects mirror an awareness of this special position. Claiming that it was "only through photography that the beauties of this State can be displayed for the admiration of the East and the rest of the world," members defined their practice in unison with the particular geography of the region (Editorial). Their ideal, articulated by president Erwin in Camera Craft, would consist in "portray[ing] the whole of California as has never been done before" and thereby "assist in the material welfare of the state and the Pacific Coast" (Erwin, "A Pacific League" 14). Through a search for the members who pursued the goal of enriching regional culture, we can retrace the Club's commitment to actively forging, promoting, and disseminating a visual history of California between the 1890s and the 1910s.

To identify the most active members and their contributions to this local-historical archive, the reliance on publications in the West Coast photography journals is key. For more than three decades, scholars have argued in favor of an inclusion of magazines in photo-historical research (Siegel and Stiegler). The source material to be derived from the Club's widely read Camera Craft - the only journal based and edited in the American West - represents a coherent addition to an otherwise scattered corpus. From its pages ensues a detailed picture of the Club's agenda that reached wider audiences thanks to its circulation of 6,000 copies per month ("Notes" 394). To researchers today, its articles and halftone reproductions provide assistance in unearthing source material from 1900 up until the 
early 1940s. Prior to the launch of Camera Craft, practitioners relied on the Pacific Coast Photographer, published in San Francisco monthly between 1892 and 1894. Although rather short-lived, its contents give insight into the beginnings of Club activity. It reveals three key contributors-Charles B. Turrill, commissioner for universal expositions and collector, Oscar V. Lange, eminent professional and promoter of local history, as well as Thomas P. Andrews, Club secretary and business partner of Lange's. Through an exploration of their written exchanges, we may retrace their productions and, more broadly, the collecting institutions that hold Club material today.

Probably the most fruitful undertaking that defined the Club's first decade was the dual preparation of the World's Columbian Exposition in Chicago in 1893 and the California Midwinter International Exposition in San Francisco the following year. Even though the Club did not stage its own exhibition at either of the two fairs, its members came to recognize the importance of showcasing local achievements through photography. As historian Max Quanchi has argued, photographic illustration and circulation became key tools in an era when the U.S. moved "from isolationism to an expansionist international agenda" (213-17). Accordingly, at the California fair, photographic displays served to insert the state into the emerging celebratory narrative of the nation. The decisive figure who invited Club members to participate was Charles B. Turrill. As commissioner of California for preceding universal expositions and employee of the Southern Pacific railroad's passenger department which invested massive sums in tourist promotion, Turrill had actively shaped the state's promotional vocabulary (Orsi 137-38). More importantly, he was an ardent collector of books, manuscripts and photographs related to Californian history - an interest that led him to publish numerous histories of the state, and even a biography of photographer Carleton Watkins (Fels, Documenting Eden n.p.). Running a photographic firm in the 1900s, Turrill was closely acquainted with members of the Club. By early 1892, when a "dress rehearsal" for the California building at the Chicago Fair was planned in San Francisco, he reached out to then Club secretary Thomas P. Andrews to request a photographic contribution.

Turrill's idea of showcasing photographs of California scenery had been particularly well received in Club circles in the run-up to the exhibition. One contributor in the Pacific Coast Photographer considered it the recognition of "the value of photography as a means of conveying knowledge" (J.E.B. 236). Today, a researcher consulting Turrill's work in the Bay Area's collecting institutions soon recognizes the wealth of photographic materials and correspondence related to this endeavor. His papers, preserved at the Bancroft Library in Berkeley, include correspondence with Andrews. In numerous letters exchanged during the summer of 1892, Turrill describes himself as "particularly desirous" of a Californian photography display at the Fair which he thought "[would] redound to its credit and to the advancement of photography" (Turrill Papers I, fol. 3). According to the commissioner, 
the showcasing of aesthetically pleasing photographs, next to landscape paintings, was to attest to the state's artistic potential. In line with the period's discourse of California as an "American Mediterranean" (Starr 365-414), Turrill insisted on the region's resourceful climate. Predicting California's role for the dawning twentieth century, he announced "a civilization, of letters and art, far greater than those in their sunniest days, made Greece and Rome famous" (Turrill Papers I, fol. 3). Yet despite the strong belief in the medium's capacity to illustrate a sophisticated and aesthetically pleasing Californian culture, Turrill's request did not materialize in a collective Club submission to the dress rehearsal.

In spite of this failed request, the commissioner further pushed for local preservation by demanding the establishment of a museum of Californian history after the Chicago fair. Turrill envisioned a collection consisting of objects displayed at the fair, enriched by local photographers' works and material from the Society of California Pioneers to which he was, at the time already, an active contributor (Turrill Papers I, fol 3). Thanks to these announcements in the journal and written exchanges, the Society and its holdings emerge as a key venue. Resident photographers often sought to contribute to these archives, as their holdings constitute the onset of local-historical preservation. Commonly identified as the first collecting institutions in remote territories, "pioneer" institutions like the California Historical Society were fundamental to community-building the American West. They not only celebrated an "idealized" narrative of settlement, but also helped forge a "shared" local memory (Milner 213-15). Through collaboration with these societies, practitioners purposefully inscribed themselves in communal history and inserted their works into a valuable collection. Turrill's residue at the Society of California Pioneers, including thousands of photographic objects by himself and his acquaintances, manifests this desire. It makes us aware of the importance of the numerous involvements Club members had in civic matters and regional promotion (Watts). Their uses of the medium, and especially their ambitious preservation projects, enrich our understanding of photography's functions in a nascent Northern Californian culture.

To complete this picture, it is useful to shed light on the two figures whose output probably ranks among the most conspicuously overlooked in California's photographic history. Oscar V. Lange, along with his business partner and fellow Club member Thomas P. Andrews, counted among the region's most active photographers during the 1890s. Both members cultivated an interest in preserving and promoting Californian culture. Andrews, when Club secretary, was not only acquainted with Turrill, but had gained prominence himself as a professional photographer. He was famous for his 2,000-item negative collection of local views among which Chinatown was extensively covered. ${ }^{2}$ In

2. Parts of Andrews' collection were donated by his granddaughter to the Achenbach Foundation at the Legion of Honor Museum in San Francisco. 
order to identify the contributors to this nucleus of San Franciscan photography, it is useful to consider local newspapers. Next to specialized journals, they constitute valuable additions that allow us to assess the prominent place of practitioners in society. Daily publications like the San Francisco Chronicle regularly ran articles on photographic developments in the region. In the section "The Camera in California," the editors praised Andrews for exactly this vast collection of views and identified his business partner Lange as one of the city's most active practitioners (9).

In the framework of the exposition, both photographers fine-tuned their approach to photographic preservation. When parts of the Chicago Fair were reconstructed in San Francisco on the occasion of the Midwinter Fair in early 1894, the city's businesses, institutions and promoters were keen on proving "civilization's presence on the continent's edge," in a region that had gained notoriety for the Gold Rush a mere four decades earlier (Berglund 171-77). To emphasize these achievements, notably as regards the cultivation of an intellectual environment, Lange collaborated with the University of California at Berkeley (UCB) for its exposition pavilion. His large format prints, neatly framed and displayed on the fairgrounds, showed the idyllic setting of the campus, students engaged in outdoor activities, and the numerous departments of the university, alongside classrooms and laboratories. Lange, who had been closely acquainted with the university staff, drew on these insights to contribute to the idealized image of Californian culture (Görgen "Historiens").

As his display constituted a rather ephemeral contribution, he sought to consolidate his documentation by donating the framed exhibition prints to the university library after the Fair. Assisted by Andrews, Lange assembled three large-format albums with salted paper prints of his UCB views. The two also produced more than one hundred lantern slides of the campus that were shown to San Francisco's inhabitants and to publics across the nation in a lecture entitled "Through the University of California with a Camera." This extremely varied collection of photographic objects - including prints, albums, lantern slides and lecture instructions - is available at the Bancroft Library on the UCB campus today - an institution which houses numerous other items by Lange. The methodology and material supports Lange and Andrews adopted are reminiscent of the National Photographic Records Association's systematic pursuit of photographic preservation. The salted paper prints used in the UCB albums were popular with camera clubs for their matte surface and soft tones (Kennel 71). They emulated the methods of San Francisco's earliest photographers, such as George Fardon, who used salted paper for his ostentatious albums of the city in the 1850s. The UCB albums reflect the photographers' keen awareness of historical preservation of and through photographs. Inside the cover, they included a recommendation that the views of the Fair "be carefully stored [...] for future exhibitions," and that its duplicates "be deposited with the Librarian, to be mounted in portfolios, as a permanent historical record of the University in 1894" (Lange n.p.). 
After securing a storage location for the albums, Lange sought out a more dynamic material support to circulate the triumphant narrative of the views in public - far beyond the actual Midwinter exposition. As lantern slide lectures were used across the country by camera clubs to celebrate "civic pride" (Greenough 271), Lange's UCB slides can be inserted in this tradition. By the late 1890s, he had assembled a lecture in the shape of a walking tour on campus. A coherently organized sequence, the lecture was instilled with the frequently used vocabulary of Californian exceptionalism which, in this case, identified the campus as "the future Oxford of the Western Empire" (Lange, "Through" fol. 27). As the slides were disseminated along with a meticulously detailed transcript through the Lantern Slide Interchange, San Francisco's celebratory narrative could be staged almost identically in locations across the country without necessitating the photographer's actual presence. Through this choice of material supports, Lange ensured that the Midwinter Fair's glorification of California was to be preserved by historical institutions in the Bay Area - and internalized by viewing publics across the nation. Again, here, researchers of Californian photography do not only have access to this material through the library catalog. Upon closer inspection of articles in Camera Craft, they are also made aware of Lange's eminent contributions. When Lange died in 1913, twenty years after the Fair, he was remembered by the editors for exactly these works. They pointed to the UCB lecture as his most important achievement that had been "enjoyed" by audiences "throughout the country" ("Professor Lange" 32).

From this examination of the Club's most important contributors ensues a reconsideration of the storage locations and sources commonly expected of photographic materials of the turn of the century. In lieu of pristine individual prints and salon catalogs, the researcher encounters a variety of supports - visual and textual — which point to the versatile uses of photography by camera club members. By shifting the perspective from a formalist to a sociocultural gaze, we come to discover a broad range of hitherto unknown sources. In this context, the writing about photography in journals and newspapers is just as important as the actual productions, as it reveals the social expectations and historical desires attached to the medium. Furthermore, these written traces help us identify major storage locations, as in the case of the Society of California Pioneers and the Bancroft Library. If we follow art-historian Glenn Willumson's proposal of "a fresh set of criteria" that include "the materiality of the photograph and its trajectory over time," we allow for exactly these sources to emerge (78). In their heterogeneity and their incongruity with the existing categories, they help articulate a new history of photographic practice. If we want to ask how this panorama of photographers, written materials, and local institutions has disappeared from the canon, it is exactly this collective understanding of the medium - and its appreciation over time - that requires closer scrutiny. 


\section{California's photographic history in the 1930s: Retracing the absences}

Probably the most remarkable aspect of the California Camera Club's decade-long activity in the state was its constant appeal to new members. If its membership had reached a nationwide peak of 425 in 1900 , these numbers remained stable even in the aftermath of the earthquake and fire. A mere year after the destruction, in the summer of 1907, a committee of eighty members relaunched an annual excursion agenda to the Yosemite with the goal of refurnishing the Club archives - a goal that was achieved in this outing alone, generating some 1,500 negatives (LeBreton 301). In the long run, by 1912, the rollcall still indicated 230 active members, and more than 120 subscribers to activities such as outings and lectures (Chase and Hoyt). When seeking to understand why the Club disappeared from the region's photographic history, we need to take into account exactly this large-scale participation. In the light of many photo-historians' "[strong bias] in favor of the Stieglitz circle," it is essential to recognize that the exclusivist criteria of the Photo-Secession have become the reading grid through which the majority of American turn-of-the-century photographic material is appreciated (Davis 69). Its handpicked membership of fellows and associates, as well as its rigorous aesthetic principles - purposefully forged by Stieglitz - have had long-lasting repercussions on the understanding of photography around 1900. Marginalized by this exclusive model, the photographers of the California Camera Club produced a corpus which cannot be unified under a specific label. Its membership opted for inclusion rather than elitism, and thereby embraced practices that blended commercial and artistic interest. While the Club lacked a coherent preservation practice and thus, in the long run, failed to produce a unified corpus, its absence in the photographic histories of region is just as much due to the monographic fashion in which this history has been articulated from the 1930s onward - as one curator put it — "[from] Watkins to Weston" (Fels, Watkins to Weston n.p.).

A key figure to shape this Californian "master" narrative was Ansel Adams. As a young photographer growing up in San Francisco, Adams had started out as a member of the California Camera Club. Yet, by the early 1930s, and notably after meeting Alfred Stieglitz in what his biographer described as a "momentous" and "life-changing" encounter, Adams decided to adopt the New Yorker's strategy of photographic appreciation (Alinder 135-40). Since a monographic narrative was required to achieve the insertion of the medium into the fine-art tradition, Adams engaged in photographic writing, collecting and in the establishment of California's very own secessionist formation-Group f/64. As recently argued by Rachel Sailor, Adams's attempt "to rarify [...] photography" — which was considered an absolute necessity for the autonomization of the medium - allowed him to "[manipulate] the discourse on western landscape photography by aligning himself with the eastern fine art tradition introduced by $[\ldots]$ Stieglitz" $(135,149)$. This creation of aesthetic continuities - from Timothy O'Sullivan and 
Carleton Watkins to Edwards Weston and Adams himself - provided the photographer with a model for institutional appreciation. When staging their exhibitions in the early 1930s, Adams and his peers at Group f/64 based their manifesto on Stieglitz's rigorous ideals and re-enacted a Secessionist movethis time from the still thriving Californian Pictorialist scene. Around the same time, Adams became acquainted with the staff of the newly founded San Francisco Museum of Art. When its photography department was established in 1940, he insisted that if the museum were to develop a legitimate collection, it "needed to distance itself from the amateur groups that had been given frequent exhibitions in the past" (Phillips 99) - thus rejecting Club productions. Adams inserted his very own selection of photographic masters into the institution by appreciating former Club members like Arnold Genthe, whose output could easily be framed as the West Coast's German intellectual counterpart to Stieglitz (Birken 97-99). At the same time, he left out advocates of collective practices like Turrill or Lange, whose works were more heterogeneous. His was a selection process that championed uniformity over eclecticism - and as such, brushed aside the presence of the numerous camera clubs in what would become the West Coast's most important photography collection.

The later history of the Club demonstrates how its communal agenda further excluded it from the local art institutions that were founded at the time. From the 1910s to the period of photography's institutionalization in the 1930s, the CCC reinforced its self-proclaimed status as a "state organization" by diversifying its agenda, notably through guided tours to Yosemite on trains and by automobile (Chase and Hoyt 9). Here, the practice of photography became an ideal tool—not intended to be perfected per se, but rather to allow the local population to appreciate the Californian out-of-doors. Two photograph albums of an unknown Club member of the period attest to this ambition, as they include extensive documentation of outings to more than fifty locations throughout Northern California. ${ }^{3}$ At the same time, around 1917, the Club donated its Yosemite excursion programs as well as its calendar of exhibitions and lectures to the newly opened branch of the California State Library (CSL) in San Francisco. As a CSL librarian remarked, local organizations like the CCC "were most likely encouraged in the beginning stages of the library to add this bit of history to the California History Collection" (Paige). While it is unclear which materials were demanded by the CSL, it is remarkable that the Club exclusively selected documents that reflected its social program. Rather than donating photographic materials, members would inscribe their function as a communal organization into the history collection. This decision is symptomatic of the Club's archival legacy which reflects its communal engagements. Notably, in 1935, when the Club eventually donated photographic objects (in the shape of a lantern

"Photograph album with photographs documenting California Camera Club Outings, 1917-1924" (photCL 438), The Huntington Library, San Marino. 
slide collection of the 1915 Panama-Pacific International Exposition), its members opted for the San Francisco Public Library-yet another institution which was to reflect its local commitment. ${ }^{4}$ This civic agenda was pursued until mid-century, when the Club became part of the city of San Francisco's Recreation and Park Department with which it continued its outing schedule.

The San Franciscan development of a "master narrative" is symptomatic of the division of the history of American photography into, on the one hand, a fine-art canon of a handful of "photographers of genius" (Naef Photographers), and on the other hand, a "sociohistorical" category to which the variety of amateur, professional and anonymous productions were loosely assigned. From this process ensued, over the course of the twentieth century, two strands of photo-historical research. The first, as discussed above, appeared by the 1930s under the auspices of MoMA curator Beaumont Newhall and advanced an individualized, artistic focus which has turned into a largely unchallenged, general history of American photography (McCauley "Writing"; Brunet "Robert Taft"). The second strand, as exemplified earlier, consisted of local libraries and historical societies which had preserved photographic objects alongside correspondence, manuscripts and other more eclectic items. This latter category, as explored in the research of Sandweiss and Sailor, inserted the medium into a sociocultural context that allowed for an unexpected breadth of sources to emerge. Exactly this enlarged perspective is required when considering camera club materials. Rather than being lone practitioners, members were closely engaged in civic matters, and therefore sought out regional collecting institutions from the onset. This communal strategy of photographic practice and preservation becomes evident through the California Camera Club. As it did not opt for one leader to unite the group but instead reached out to a broad base of participants, it produced works that became part of historical societies, public libraries, municipal collections and in some cases also museums. Through a focus on material supports and their trajectories, new research may include the albums, lantern slides and correspondence residing in these repositories. In their variety, they reflect the importance the photographers attributed to the medium in their communities.

As this brief reconstruction of the Club's history shows, the history of oblivion with regard to American camera clubs is very much informed by choices of social organization, material support, and storage venue. Opting for a large-scale membership with a highly eclectic material output which it failed to preserve coherently, the CCC was omitted from the monographic fine-art histories articulated since the 1930s. The numerous engagements in civic society that are difficult to survey in terms of participation and output disqualified its members from these photographic histories. And yet, these

"California Camera Club Lantern Slide Collection of the Panama-Pacific International Exposition" (SFP 79), San Francisco History Center, San Francisco Public Library. 
myriad undertakings and imaginative discourses are exactly the factors which turn the Club into a highly interesting case study for developing new methodologies of photo-historical research for the 1900s.

\section{New methodologies for exploring camera club corpora: Toward a "photography complex"}

If research in the American West has, for the most part, concentrated on individual figures, there have been important advocates in favor of a sociohistorical approach, among whom Californian photographer-historian Peter Palmquist probably ranked as the most vocal. Amid discussions of critical photo-historical scholarship in the 1980s, Palmquist collected and published on mostly unknown figures, all the while taking into consideration the specific sociocultural and economic ramifications of practice in the Pacific West. From early on, he suggested that " $[\mathrm{t}]$ o study photography as material culture, the net must be cast wide. One cannot solely rely on assessments based on art historical methods, nor can one make a case based on a few major institutional collections with their built-in biases" (Earle 2). This approach materialized in Palmquist's collection which today includes a total of 9,000 practitioners - each of whom is presented in a folder containing a micro-archive of photographic output. ${ }^{5}$ His understanding of photo-history as informed by a broad set of actors, institutions, and materials has substantially shaped the collection. It constitutes a crucial tool to reconstruct the network of camera club members. Unsurprisingly, the folders he assembled for Lange, Andrews, and Turrill include a majority of the afore-mentioned items, ranging from prints to articles and advertisement.

If Palmquist's hands-on approach to photographic history resulted in such a heterogenous collection, scholars have sought to conceptualize this holistic approach in recent years. Advocating for a study of the "material culture" of camera clubs that includes prints, catalogs, journals, and exchange objects like prize medals, Elizabeth Edwards endorsed a new understanding of club archives as dense physical entities which shed new light on photographic practice in the early twentieth century (145). On a more general note, the era around the turn of the century - when photographers became aware of the medium's versatility and developed new reproduction technologies - has been labeled by historian James Hevia as the "photography complex." Beyond the net of actors, instruments and institutions, this complex also joins "the staggering array of reproductive technologies through which images [...] circulate" with "the production and distribution networks that link far-away places to end-users."

The Peter E. Palmquist Collection of Male Photographers in the American West, Yale Collection of Western Americana, Beinecke Rare Book and Manuscript Library, ca. 1840-2003 (WA MSS S-2733). 
Through this unifying concept, Hevia rallies awareness for the agents and platforms that were necessary for photographic production. At the same time, he considers the archival encounter with photographic objects as a critical step in understanding "cultural formation" (81).

As demonstrated earlier, the definition of such a broad set of actors profoundly changes our perception of photography around 1900 as it brings to the fore the practitioners' daily interactions with their community, environment, and local support system. The latter is especially important, as it includes institutions, whose holdings have long been overlooked due to a restrained focus on museum collections. Therefore, next to broadening our archival methodology by including local institutions and varied material supports, we just as much need to develop a critical gaze on the medium's historiography. As shown before, the dominant fine-art strand of photographic preservation since the 1930s has had considerable impact on contemporary understandings of the medium. Conversely, the less explored strand of "social history" needs reconsideration as it was formulated at the same time as the New York-centered narrative gained impetus. Here, the re-appreciation of Kansas professor Robert Taft is crucial as he argued in favor of "a social history" and cultivated a profoundly local understanding of the medium at the same time as Newhall and MoMA's establishment sought aesthetic continuities (Brunet, La Photographie 209-64). Recent scholarship on photography in the American West has relied on Taft's proposal of the 1930s "that local historians would find a fertile field of research [in state and local historical societies], not only in locating [...] material, but in preparing brief photographic histories of their localities" (Taft qtd. in Sailor 165).

Today, eight decades later, this localized approach to photographic history is immensely facilitated through digitization. Online collections display the amount of material to tap and reveal hitherto unknown production networks. Thanks to the digitization endeavors of precisely the local institutions that Taft had referred to, photo-historical research has become increasingly accessibleespecially to scholars residing outside the US. This facilitated access becomes manifest for example in the digital photography collection published by six Californian institutions on the centennial of the San Francisco earthquake and fire in 2006, which allows researchers from across the globe to explore local holdings ${ }^{6}$. Even though the digital format has shortcomings, it does provide a fertile point of departure for surveying hitherto unknown photography collections. Perhaps exactly because of this new availability of digital documentation, our awareness of photographic materiality and conditions of archival preservation has been sharpened. Thanks to this rediscovery of regional collections and the improvement of a photographic digitization technology, the field of photo-historical inquiry into

The 1906 earthquake and fire collection: http://bancroft.berkeley.edu/collections/earthquakeandfire/index2.html (page accessed 14 May 2019). 
camera clubs is especially promising. Inasmuch as these clubs of the turn of the century were animated by "the fear of a future unaware of its past" and therefore engaged in extensive documentation of the local territory (Edwards 22), it is up to researchers of this new century-with new tools at hand-to uncover the photographers' methods of collectively engaging with the past and the future. In doing so, we not only shine light on a new web of actors, but also engage with the material and imaginative expectations of the photographic medium around 1900.

\section{Conclusion}

When seeking to reconstruct the dynamic network of photographic actors in a period when the medium became accessible to larger parts of society, it is crucial to adopt the same versatile approach to photography that its practitioners cultivated. Since camera club members were first and foremost inhabitants of communities in a period of national identity-building, we need to understand their practices, productions, and discourses from exactly this perspective. Through an examination of a broad web of contributors - amateur, professional, political, and artistic - the embedded nature of photography around 1900 comes to the fore. As the case of the California Camera Club demonstrates, a scattered corpus does not necessarily hamper the articulation of a photographic history. Instead, through the adoption of a rigorous methodology that considers written sources, material supports, and often overlooked institutions, a more complex history of the medium emerges.

The most important point of departure - set against a purely visual reading — is the body of written sources in photography journals, newspapers and popular magazines. Since photographers cultivated a discourse that was shared and nourished on written platforms, scholars may rely on these contents in order to systematically retrace contributors. With such a newly assembled list of practitioners, we can approach the numerous local institutions. By expanding the frame of inquiry - far beyond the edges of photographic prints and the walls of museums - we then come to discover new material supports and storage locations. In the Californian case, the unearthing of such written sources has revealed an intense awareness of photographic preservation and local history. By expressing their beliefs in the photographic medium for a widespread appreciation of Californian culture and for collectively articulating the history of a community on the edge of the continent, the membership used the storage potential of the archive as an impetus to their practice. As historians of photography and of visual culture at large, we need to consider exactly these shared imaginary discourses. For the early twentieth century, this implies a shift in perspective from a fine-art-centered approach to a focus on the uses and functions of the photographic medium in society. 
While this new methodology does not necessarily enable us to retrieve every single item among the "thousand plates" on which San Francisco was to be imprinted in 1901, it does provide us with new material to counter the monographic canon of photographic masters. This canon can be challenged by extending regional geographies, by questioning linear chronologies, and by uncovering long-forgotten archival boxes. To explore a neglected corpus then represents an opportunity to rethink the ways in which we approach photographs, their makers, their institutions, and histories. It activates a process of reinserting photographs into a context where they can exist as objects in their own right, and where their makers become authors. In other words, the extreme versatility of camera club members demands the same degree of flexibility on the part of the researcher.

\section{Works Cited}

ALINDER, Mary Street. Group f.64: Edward Weston, Ansel Adams, Imogen Cunningham and the Community of Artists Who Revolutionized American Photography. New York: Bloomsbury Publishing, 2014.

BERGLUND, Barbara. Making San Francisco American: Cultural Frontiers in the Urban West, 1846-1906. Lawrence: University Press of Kansas, 2007.

BIRKEN, Jacob. "Die Kalifornische Institution. Fernwestliche Weltbilder um 1906.” PhD diss., Staatliche Hochschule für Gestaltung Karlsruhe, 2018.

BIRT, Rodger C. "The San Francisco Album and Its Historical Moment: Photography, Vigilantism and Western Urbanization.” San Francisco Album: Photographs 1854-1856. Ed. Jeffrey Fraenkel. San Francisco: Chronicle Books, 1999. 99-125.

BRUNET, François. La Photographie Histoire et Contre-histoire. Paris: Presses Universitaires de France, 2017.

—_. "Robert Taft in Beaumont Newhall's Shadow: A Difficult Dialogue between Two American Histories of Photography." Études Photographiques 30 (2012): 45-69.

CHASE, Maude E. and Herman S. HOYT, eds. First Annual California Camera Club. San Francisco: California Camera Club, 1912.

DAVIS, Keith. An American Century of Photography: From Dry-Plate to Digital, $2^{\text {nd }}$ ed. Kansas City and New York: Hallmark Cards, Inc. and Harry N. Abrams, Inc., 1999.

EARLE, Edward W. Introduction. Return to El Dorado: A Century of California Stereographs from the Collection of Peter Palmquist. Ed. Peter Palmquist. Riverside: California Museum of Photography, 1986. 2-3.

Editorial. Camera Craft 2.1 (1900): 47. 
EDWARDS, Elizabeth. The Camera as Historian: Amateur Photographers and Historical Imagination, 18851918. Durham: Duke University Press, 2012.

ERWIN, James W. “A Pacific League of Camera Clubs.” Camera Craft 1.1 (1900): 14.

—_. "A Photographic Army to Impress San Francisco on a Thousand Plates." Camera Craft 3.6 (1901): 237-238.

FELS, Thomas Weston, ed. Documenting Eden: The Wine Country Photographs of Turrill \& Miller. San Francisco: The Society of California Pioneers, 2005.

- Watkins to Weston: 101 Years of California Photography, 1849-1950. Santa Barbara and Niwot: Santa Barbara Museum of Art in cooperation with Roberts Rinehart Publishers, 1992.

FRADKIN, Philip L. The Great Earthquake of Firestorms of 1906: How San Francisco Nearly Destroyed Itself. Berkeley: University of California Press, 2005.

GÖRGEN, Carolin. “'Des cendres à la nouvelle métropole' : Le California Camera Club et la reconstruction photographique de San Francisco au lendemain du tremblement de terre et l'incendie de 1906." Translated by Pierre Von-Ow et al. Transbordeur 2 (2018): 186-199.

_. "Historiens du territoire et de la pratique : Les photographes du California Camera Club." Histoire de l'Art 80:1 (2017). URL: http://blog.apahau.org/revue-histoire-de-lart-n-80-varia-carolin-gorgen-historiensdu-territoire-et-de-la-pratique-les-photographes-du-california-camera-club/ (page accessed 14 May 219).

—. "“Out here it is different': The California Camera Club and community imagination through collective photographic practices. Toward a critical historiography, 1890-1915.” PhD diss., Université Paris VII Denis Diderot and École du Louvre, 2018.

GREENOUGH, Sarah. “'Of Charming Glens, Graceful Glades and Frowning Cliffs': The Economic Incentives, Social Inducements and Aesthetic Issues of American Pictorial Photography." Photography in Nineteenth-century America. Ed. Martha A. Sandweiss. New York and Fort Worth: Harry N. Abrams, Inc., Publishers with the Amon Carter Museum, 1991. 258-281.

HEVIA, James L. "The Photography Complex: Exposing Boxer-Era China (1900-1901), Making Civilization.” Photographies East: The Camera and its Histories in East and Southeast Asia. Ed. Rosalind C. Morris. Durham: Duke University Press, 2009. 79-119.

J.E.B. “California Photography.” Pacific Coast Photographer 2.1 (1893): 236.

JOSCHKE, Christian. Les Yeux de la Nation. Photographie Amateur et Société dans l'Allemagne de Guillaume II (1888-1914). Dijon: Les Presses du Réel, 2013.

KENNEL, Sarah. In the Darkroom: An Illustrated Guide to Photographic Processes before the Digital Age. London and New York: Thames \& Hudson, 2010. 
KROIZ, Lauren. Creative Composites: Modernism, Race and the Stieglitz Circle. Berkeley: University of California Press, 2012.

LANGE, Oscar V. "Photographs of the University of California," 1894 (ff 308gv 1894, vol. 1-3). The Bancroft Library, University of California, Berkeley.

—. "Through the University of California with a Camera" 1899 (f 308gv 1899 L274). The Bancroft Library, University of California, Berkeley.

LEBRETON, Albert J. “The Camera Club’s Yosemite Outing.” Camera Craft 14.7 (1907): 301-309.

McCAUlEY, Anne. Clarence H. White and His World: The Art \& Craft of Photography, 1895-1925. New Haven: Yale University Press, 2017.

—_. "Writing Photography's History before Newhall.” History of Photography 21:2 (1997): 87-101.

MILNER II., Clyde A. "The View from Wisdom: Four Layers of History and Regional Identity.” Under an Open Sky: Rethinking America's Western Past. Eds. William Cronon, George Miles and Jay Gitlin. New York: W.W. Norton \& Company, 1992. 203-222.

MIOTTEL, Katrina. “"Rebellion in Photography': Northern California Photographers at the Turn of the Century.” Unpublished Master thesis, Stanford University, 1985.

NAEF, Weston J. The Collection of Alfred Stieglitz: Fifty Pioneers of Modern Photography. New York: The Metropolitan Museum of Art and the Viking Press, 1978.

—. Photographers of Genius at the Getty. Los Angeles: J. Paul Getty Museum, 2004.

“National Photographic Record Association.” American Amateur Photographer 13 (1901): 492.

"Notes." The Photo-Miniature 2 (1900-1901): 394.

ORSI, Richard J. Sunset Limited: The Southern Pacific Railroad and the Development of the American West, 1850-1930. Berkeley: The University of California Press, 2005.

PAIGE, Karen (Librarian, California State Library). E-mail message to author, April 18, 2017.

PHILLIPS, Sandra. "In the Beginning: Photography at the New San Francisco Museum of Art." San Francisco Museum of Modern Art: 75 Years of Looking Forward. Eds. Janet Bishop, Corey Keller and Sarah Roberts. San Francisco: San Francisco Museum of Modern Art, 2009. 95-105.

"Professor Lange Passes Away." Camera Craft 21:1 (1914): 32.

QUANCHI, Max. “Imaging the USA's Pacific Empire.” History of Photography 39.3 (2015): 213-226.

SAILOR, Rachel. Meaningful Places: Landscape Photographers in the Nineteenth-Century American West. Albuquerque: University of New Mexico Press, 2014. 
"San Francisco on a thousand plates": New perspectives on photo-historical research...

SANDWEISS, Martha A. Print the Legend: Photography and the American West. New Haven: Yale University Press, 2002.

SIEGEL, Steffen and Bernd STIEGLER, eds. "Schreiben über Fotografie" Fotogeschichte 37 (2017). 3-4.

SOLOMON-GODEAU, Abigail. Photography at the Dock: Essays on Photographic Histories, Institutions and Practices. Minneapolis: University of Minnesota Press, 1991.

STARR, Kevin. Americans and the California Dream, 1850-1915. New York: Oxford University Press, 1973.

TAFT, Robert. Photography and the American Scene: A Social History, 1839-1889. New York: Dover Publications, Inc., 1938.

“The Camera in California." San Francisco Chronicle (June 24, 1893): 9.

TURRILL, Charles B. Papers (BANC MSS C-B 545 Box 1). The Bancroft Library, University of California, Berkeley.

WATTS, Jennifer A. "Picture Taking in Paradise: Los Angeles and the Creation of Regional Identity, 18801920." History of Photography 24.3 (2000): 243-251.

WILLUMSON, Glenn. "Making Meaning: Displaced Materiality in the Library and Art Museum." Photographs Objects Histories: On the Materiality of Images. Eds. Elizabeth Edwards and Janice Hart. London and New York: Routledge, 2004. 65-83.

WILSON, Michael G. "Northern California: The Heart of the Storm." Pictorialism in California: Photographs 1900-1940. Eds. Michael G. Wilson and Dennis Reed. Malibu and San Marino: The J. Paul Getty Museum and the Henry E. Huntington Library and Art Collections, 1994. 1-22.

\footnotetext{
Abstract: With a focus on the dispersed corpus of an American photographic society - the California Camera Club - this article proposes new methods to examine photographic objects produced around 1900. In a period commonly defined by Pictorialism and the New York Photo-Secession, the works of San Franciscan photographers stand out as extremely versatile. The Club corpus, which has withstood the earthquake and fire of 1906, and decade-long oblivion on the part of scholars and curators, is dispersed over numerous Californian institutions. As such, it represents an important contribution to American photographic history that demands us to rethink the categories generally ascribed to camera clubs. To grasp how the works of the more than 400-member-strong organization can be partly reassembled, this article proposes a survey of the Club's primary sources with a special focus on their material supports and their storage locations, accompanied by a historiographical discussion. By looking first at the productions of the members in their most active period, and, as a second step, examining the processes of canonization which led to their oblivion, this article provides new tools for photo-historical research around 1900.
} 
Résumé : En se concentrant sur le corpus dispersé d'une société photographique américaine, le California Camera Club, cet article propose de nouvelles méthodes pour examiner des objets photographiques produits autour de 1900. Dans une période dominée par le Pictorialisme et la Photo-Secession de New York, les travaux des photographes de San Francisco se démarquent par leur polyvalence. Le corpus du club a résisté non seulement au tremblement de terre et l'incendie de 1906 mais a également survécu à l'oubli de la part des chercheurs et des conservateurs. Il se trouve aujourd'hui dans de nombreuses institutions californiennes. Il représente une contribution importante à l'histoire de la photographie américaine et nous demande de repenser les caractéristiques généralement attribuées aux caméra clubs. Pour comprendre comment les travaux de cette organisation de plus de 400 membres peuvent être reconstitués partiellement, cet article propose une étude détaillée des sources primaires qui met l'accent sur leurs supports matériels, leurs lieux de conservation et le contexte historiographique. En analysant d'abord les productions des membres durant la période la plus florissante et en retraçant ensuite les processus de canonisation qui ont mené à leur oubli, cet article fournit de nouveaux outils pour la recherche en histoire de la photographie autour de 1900. 